\title{
A siófoki kórház és a magyar kórházügy jelese: Varga Ferenc (1942-2013)
}

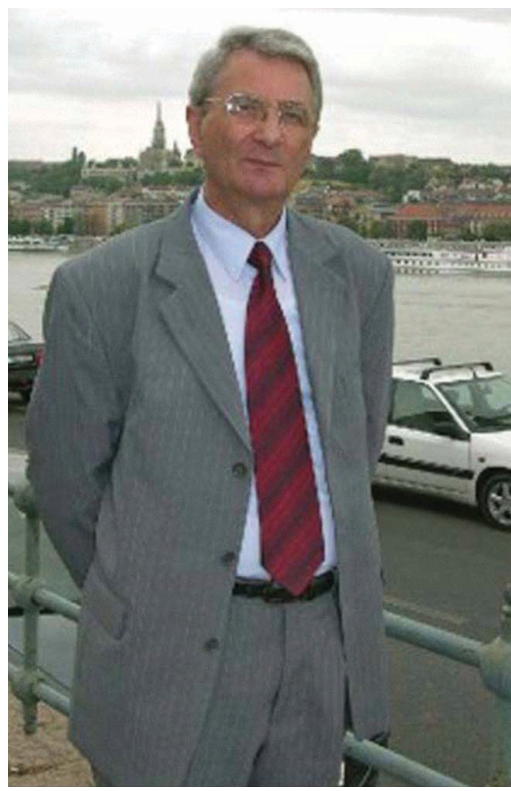

1. ábra

| Dr. Varga Ferenc, 1998-2000: a Magyar Kórházszövetség elnöke

Dr. Varga Ferenc siófoki kórházigazgató egyedülálló életmúvet hagyott maga mögött. Elkötelezettje volt a kórházi egészségügynek. A KÓRHÁZ szakfolyóirat megfogalmazása szerint: „Senki nem tud annyit a magyar kórházügyrôl, mint Ö.”

Varga Ferenccel Szentendrén ismerkedtem meg, ahol minden évben országos egészségvédelmi konferenciát rendeztünk, és az egyik alkalommal Ô is jelezte, hogy mind a három napon részt szeretne venni. Két előadást is tartott a kórházi fekvő betegek, illetve szakrendelésük ellátottjainak folyamatos egészségvédelméről. Barátságunk innen indult.

Varga Ferenc Budapesten született 1942. március 24én, és 1966-ban végzett a Pécsi Orvostudományi Egyetemen. 1970-ig a Somogy megyei KÖJÁL osztályvezetője, 1970-1977-ben Siófokon városi és járási fóorvos.

1977-ben a 35 éves fiatalember pályázat útján nyerte el a siófoki kórház igazgató főorvosi állását, s így ő lett a legfiatalabb magyar kórházigazgató. Rajta kívül nincs senki, aki 36 éven át megszakítás nélkül kórházigazgatói feladatokat látott el, ráadásul ugyanannak az intézménynek az élén. Hivatott vezetője volt a kórháznak és időszakos irányítója néhány szakmai szervezetnek. A Magyar Vöröskereszt Somogy Megyei Siófoki Területi Szerveze- tének alapító tagja és elnöke 30 évig. A folyamatos, észszerü fejlesztések mestere volt. „Forráshiányos helyzetben a lehetó leghatékonyabb szervezet kialakitása a fontos. Nem akarunk nagyobbak lenni, mint szüikséges, és többet tenni, mint lehetséges" - fogalmazta meg missziós nyilatkozatában. Nehéz gazdasági helyzetben átgondolt, sokéves munka eredményeként sikerült fenntartania az általa vezetett kórházban a pénzügyi egyensúlyt. Az igazgató szobájában 30 évig szerényen az 1977-ben örökölt bútorok maradtak. Gyakran munkatársainak spórolással megtakarított természetbeni juttatásokat igyekezett nyújtani a pénz hiányában. Szokássá vált a fejenként két kilogramm szaloncukor karácsonykor.

1983-ban a SZOT Bányász Üdülő Szanatórium és a Balatonfüredi Park Idényszanatórium megszervezésével az egészségügyi ellátást olyan területen is bóvítette, amelyre az országban addig nem volt példa. Előbb 180 ágyon az ország egész területérôl mozgásszervi és gyomor-bél bántalmakban, utóbb 90 ágyon elhízottak és végtagbetegségben szenvedők utókezelését irányította a szakintézményi elbocsátás után.

1984-ben az első országos értékelés alkalmával a kórház-rendelőintézet elnyerte az Egészségügyi Minisztérium által adományozott „Kiváló Intézmény” címet.

Amikor 1985-ben a regionális földmozgás katasztrófahelyzetet idézett elő, erősen megrongálva a kórház épületét és a régi egészségházat, az életveszélyessé vált épület kiürítése elkerülhetetlenné vált. Varga főorvos átgondolt, gyors szervezéssel és összefogással olyan átmeneti megoldásokat talált ki, hogy minden kitelepített szolgálat továbbra is múködőképes maradt.

Amikor az általa már 1981-ben javasolt kórházbővítési, -fejlesztési program megvalósítására döntés született, az új épületszárny lehetőséget adott nélkülözhetetlen részlegek (például coronariaőrző) kialakítására, korszerú ágyak elhelyezésére, új vizsgálati eljárások és módszerek bevezetésére alkalmas helyiségek kialakítására. A 20. évfordulóra elkészült az új épületrész. A kórházbővítéshez tartozott a 12 ágyas intenzív osztály kialakítása. A siófokihoz hasonló nagyságú kórházak közül elsőként történt komputertomográf (CT) beszerzése. Bevezették a hétmilliós múszer megvétele után a lézersebészetet, és alkalmazni kezdték az endoszkópos mútéti technikákat. Megépült az orvos- és nővérszálló, felújították a rendelőintézet épületét. Megvalósult a fütés korszerüsítése és a mütők rekonstrukciója. Takarékossági célból a kórház mellett mü- 


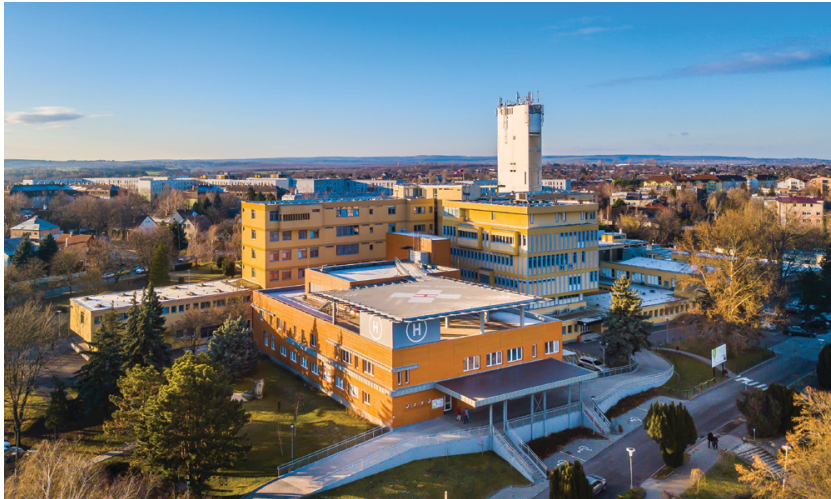

2. ábra

| A Siófoki Kórház-Rendelőintézet képe

ködő rendelőintézetet átadták az önkormányzatnak, és a járóbeteg-szakellátást beköltöztették a kórházba.

Az 1960-as évek színvonalán épült kórház felújítása során 2001-2002-ben készült el a sebészeti ambulancia és szakrendelés, valamint a rendelőintézeti laboratórium befogadására alkalmas épület. 2003-tól krónikus osztály múködött a kórházban. Az év ôszén került sor a siófoki dialízisközpont alapkő-elhelyezésére.

A 2003. május 8-án turistákat szállító autóbusz és vonat ütközése miatt bekövetkezett tömegkatasztrófa során mutatott példás szervezéséért az egészségügyi miniszter dicséretben részesítette.

2006-ban, központi rendelet alapján, tilalom alá kerültek az onkológiai szakrendelésen végezhető kemoterápiás kezelések. Folyamatosan érvelt, tárgyalt, bizonyított, gondoskodott a szakmai feltételekról. Végül sikerült elérnie célját. Ugyanígy mentette meg a kórházat 2006ban a miniszteri tervezet szerinti elsorvasztástól. Hoszszas küzdelem után, utólagosan került kiemelt (súlyponti) kórházi kategóriába az intézmény.

A 2000-es évek informatikai fejlesztésével elérte, hogy a kórház minden egysége egységes informatikai rendszerben dolgozhasson. A betegkommunikációba bevezette az elektronikus levelezést. A kiválóan elkészített pályázat és kórházigazgatói kiemelkedő tevékenysége elismeréseként és eredményeként kapott „négymilliárd forintból 2012 nyarára európai üdülőhelyekhez méltó kórháza lesz Siófoknak”. Az önrész, több mint százmillió forint, a kórház részéről már elkülönített, biztosított volt.

Véleménye szerint is: „Az egészségügyben is meghatározó, hogy milyen felkészültséggel, döntési-vezetési készséggel kerül irányitó pozicióba valaki. A munkabelynek nem csupán belsö atmoszféráját határozza meg a vezetöi stilus, hanem kisugárzik a kórtermek ápoltjaira, az orvosi rendelök betegeire és a munkatársakra is."

Fontosnak tartotta a vezető számára is a betegekkel való foglalkozást: „A legelfoglaltabb vezetönek is szüksége van arra, hogy a vezetettek és a betegek miliőjében éljen. "Kórházi fóigazgatóként jól hasznosította a betegellátásból szerzett közvetlen információit, saját tapasztalatait. „Az emberek megnyílnak az orvos elótt, elmondják az ellátással kapcsolatos észrevételeiket." Mindig nyitott volt munkatársai véleményére is. Nem rejtőzködött zárt ajtók mögé.
Megkövetelte a szakmai színvonal növelését, a rendszeres továbbképzéseket. Elvárta a beteg alapos és tisztességes ellátását. „Bármilyen nebéz évek és problémák elótt áll az egészségügy, a legfontosabb, hogy a beteg ebböl semmit vagy csak a leheto" legkevesebbet érezze" - hangsúlyozta.

1981-tôl a kórház bőrgyógyász, kozmetológus szakorvosa. A Bör- és Nemigondozót személyesen vezette: „...gyakran segitség nélkiull magam végeztem a betegek ellátását, eloffordult, hogy naponta batvan-betvenen is megjelentek.”

1986-tól a Magyar Kórházszövetség vezetőségének, 1988-tól elnökségének tagja, 1991-től a megújított Kórházszövetség titkára, az Érdekvédelmi Szakbizottság elnöke. 1998-2000-ben a Magyar Kórházszövetség elnökeként kitúnő munkát végzett.

Tapasztalatcsere céljából az egyik igazgatókollégájával meghívásra Finnországba utazott, és több település egészségügyét, kórházszervezését tanulmányozták. Kétségkívül igen fejlett egészségügyről írhattak összefoglalókat. A Magyar Kórházszövetség elnökeként következetesen képviselte az egészségügyi ellátóhálózat átalakításának szükségességét, a korszerű szakellátás feltételeinek értéken történő finanszírozását, az egészségügyi dolgozók erkölcsi és anyagi megbecsülését, a biztonságos betegellátás körülményeinek megteremtését.

Vezetői pályafutása alatt tizenhétszer történt egészségügyi miniszteri váltás! Háromszor kellett a kórházigazgatói állásra pályáznia. A képviselőtestület meg sem pályáztatta az állást, határozatlan időre nevezték ki. A 2012-es kórházi központosítás idején nyugdíjkorhatár feletti életkora miatt kiváló munkájára tekintettel biztosították, hogy az európai uniós támogatással történt kórházfejlesztés befejezéséig a tisztjében marad. A személyének szóló bizalmat az egészségügy szolgálatában eltöltött 47 évi sokirányú és kimagasló tevékenységével érdemelte ki.

Különböző szakmai szervezetektől, önkormányzattól kapott tizennyolc kitüntetése közül néhány: Magyar Köztársasági Arany Érdemkereszt, Batthyány-Strattmann László-díj, a Magyar Egészségügyi Menedzser Klub életmúdíja, Siófokért Emlékérem, Siófok posztumusz díszpolgára.

2013. március 13-án hunyt el. A magyar kórházügy kiemelkedő személyiségétől a Medical Online-on Rácz Jenő dr., a Magyar Kórházszövetség akkori elnöke búcsúzott: „A magyar kórházügyben ikon lettél. Tapasztalatod, tudásod, bölcsességed és erkölcsi értékeid nagyon hiányozni fognak." Siófoki temetésén a szakma nevében e sorok írója búcsúztatta, Tamási Áron költői gondolataival: „Azért vagyunk a világon, hogy valahol otthon legyünk benne. Varga Ferenc egész életében az egészségügyben, a betegekért volt otthon.

\section{Köszönetnyilvánítás}

A szerző hálásan köszöni Gál Juditnak a kézirat elkészítésében nyújtott önzetlen és rendkívüli segítségét.

Vértes László dr. 